\title{
Chemical Properties and Consumer Perception of Fluid Milk from Conventional and Pasture-Based Production Systems
}

\author{
A. E. Croissant, ${ }^{*}$ S. P. Washburn, $†$ L. L. Dean, $\ddagger$ and M. A. Drake ${ }^{\star 1}$ \\ *Department of Food Science, Southeast Dairy Research Center, \\ †Department of Animal Science, and \\ ¥Market Quality and Handling Research Unit, USDA, ARS, South Atlantic Area, North Carolina State University, Raleigh 27695
}

\section{ABSTRACT}

The continued popularity of organic and natural foods has generated interest in organic milk, and use of pasture for dairy cattle is a requirement for organic production. This process may improve the health benefits of fluid milk via increases in the unsaturated fatty acid content, including conjugated linoleic acid. Because pasture-based (PB) systems vary in types of forage, it is important to understand the impact of feed on the composition and flavor of fluid milk. The objectives of this study were to compare the chemical and sensory properties of PB milk with conventional fluid milk from Jersey and Holstein cows and to evaluate consumer acceptance of those milks. Fluid milk was collected throughout the 2006 growing season from Holstein and Jersey cows located in 2 herds: one fed a PB diet and one fed a conventional total mixed ration (TMR) diet. Milk was batch-pasteurized and homogenized. Sensory analyses, descriptive profiling, difference testing, and consumer testing were conducted on pasteurized products in separate sessions. Instrumental volatile analysis and fatty acid composition profiling were also conducted. The instrumental and sensory analyses differentiated the PB and TMR milks. Greater percentages of unsaturated fatty acids, including 2 common isomers of conjugated linoleic acid, were measured in PB milks. Trained panelists documented greater intensities of grassy and cowy/barny flavors in PB milks compared with TMR milks when evaluated at $15^{\circ} \mathrm{C}$. Volatile compound analysis by solid-phase microextraction and gas chromatography-mass spectrometry separated PB and TMR milk samples. However, analyses showed no compounds unique to either sample. All identified compounds were common to both samples. Consumers were unable to consistently differentiate between $\mathrm{PB}$ and TMR milks when evaluated at $7^{\circ} \mathrm{C}$, and cow diet had no effect on overall consumer acceptance. These results

Received June 16, 2007.

Accepted July 25, 2007.

${ }^{1}$ Corresponding author: maryanne_drake@ncsu.edu indicate distinct flavor and compositional differences between TMR and PB milks, but the differences were such that they did not affect consumer acceptance. The current findings are useful to consider as interest in PB dairy production systems grows.

Key words: milk, flavor, pasture, sensory

\section{INTRODUCTION}

The dairy industry has seen great changes in production, products, and processing of fluid milk in the past $15 \mathrm{yr}$. The total number of dairy farms has decreased while the number of cows per herd and the milk production per cow have grown considerably (Blayney, 2002). An overall decrease in fluid milk consumption has been offset by higher consumption of other dairy products, such as cheese and yogurt, and increased applications of dried dairy ingredients. The volatility of fluid milk prices and a rising gap in the farm-retail price asymmetry (US Government Accountability Office, 2004) are of concern to dairy farmers. To remain competitive, many dairy farmers must look for a value-added approach to dairy operations. One such approach is pasture-feeding of cows and the possibility of a transition to organic milk production.

Consumer interest in the organic and natural food sector is growing, with current demand for organic products in the United States exceeding supply (Buragas, 2005; Organic Trade Association, 2006). The organic food market has shown an annual growth of 15 to $21 \%$ since 1997 , and organic dairy products experienced a growth of $23.6 \%$ in 2005 , resulting in $\$ 2.1$ billion in sales, or $15 \%$ of the total organic food market (Organic Trade Association, 2006). Local analysis of the Raleigh, Durham, and Chapel Hill, North Carolina, retail grocery market showed a premium of $\$ 2$ to $\$ 3$ per gallon $(3.78 \mathrm{~L})$ for organic milk over conventional milk and a $\$ 1$ to $\$ 2$ per gallon premium on milk from cows not treated with recombinant bST hormone. No available compound data have addressed the premium farmers receive for organic milk, but current supply of and demand for organic dairy products has preserved a strong 
and more consistent price paid to farmers for organic fluid milk.

With the demand for organic products on a continued upward trend, many farmers are considering the opportunities and benefits of value-added milk in pasturebased (PB) dairy farming. Pasture-feeding of cows portrays a healthy image that may provide marketing opportunities and that is also compatible with organic certification. Pasture-based feeding systems on dairy farms may contribute to health benefits for the consumer and economic benefits for the farmer. Significant increases in concentrations of conjugated linoleic acid (CLA) and unsaturated fatty acids have been reported in milk from pasture-grazed cows compared with cows fed TMR (Jahreis et al., 1997; Kelly et al., 1998; Dhiman et al., 1999; White et al., 2001). The cis-9, trans-11 CLA isomer serves as a potential anticarcinogenic agent (Ip et al., 1991; Chin et al., 1992), whereas increased intake of unsaturated fats has been linked to improved cardiovascular health (Hu and Willett, 2002). The lower milk output of grazing cows can be offset by lower feed and capital costs (White et al., 2002), and there may also be potential for premiums on a value-added product.

Fresh, pasteurized milk flavor is delicate and bland, characterized by sweet aromatic, cooked, and milk fat notes that are influenced by processing conditions and milk fat concentration, respectively. Although many factors contribute to the popularity of organic foods, flavor remains a fundamental concern. Milk composition and flavor variations have been attributed to feed, seasonal variation, and breed. Because PB dairy systems vary in the types of forage that are grown, it is essential to characterize the effect of such variations on milk composition and flavor characteristics. Previous research has evaluated volatile compounds in milk flavor from conventional and PB systems (Bendall, 2001). Flavor compounds from feeds may be transferred to milk from the cow via inhalation, digestion, and rumen gases (Shipe et al., 1962). Feed composition influences compounds of plant origin and microbial origin, which may be transferred to the milk (Buchin et al., 1998; Bendall, 2001). Several groups of compounds are believed to contribute to the flavor profile of PB milk, including terpenes, linolenic acid oxidation products, phenolics, phytol derivatives, and nitrogen heterocycles (Bendall, 2001). Numerous studies have explored the composition of milk from different breeds and feeding systems (Lawless et al., 1999; Bauman et al., 2001; Khanal et al., 2005); however, there is a lack of solid analytical sensory analysis and consumer testing directly comparing PB fluid milk with TMR (traditional feedlot feeding) fluid milk. The objective of this study was to compare the chemical properties, trained sensory panel profiles, and consumer perception of fluid milk from cows fed PB or TMR diets. Fluid milk was collected from 2 herds, each containing Jersey and Holstein breeds. Milk was collected from each breed individually at both sites and analyzed to determine fatty acid profiles, volatile content, solids composition, color, sensory profiles, and consumer acceptance.

\section{MATERIALS AND METHODS}

\section{Sample Collection}

Fresh whole milk was collected from 2 dairy research units: North Carolina State University Dairy Education Unit, Raleigh, North Carolina (farm 1); and the Center for Environmental Systems, Goldsboro, North Carolina (farm 2). Each herd included Jersey and Holstein breeds, and none of the cows were receiving recombinant bST. Farm 1 represented a facility where cows were fed a TMR with no pasture, and farm 2 represented a facility where cows were fed approximately $60 \%$ of their diet from pasture, supplemented with $30 \%$ ground corn and $10 \%$ whole cottonseed. Cattle were allowed to graze, and pasture intakes were not precisely measured. However, based on concentrate allowances of 6 to $9 \mathrm{~kg} / \mathrm{d}$ and expected DMI of 17 to $22 \mathrm{~kg} / \mathrm{d}$, depending on the size of the cow and milk production, the estimated pasture intakes would be in the range of 47 to $73 \%$ of total DM. Thus, an approximate average of $60 \%$ pasture intake was used. The TMR consisted of corn silage, alfalfa haylage, grain concentrate at $10 \%$ total CP (soybean meal, ground corn, minerals), whole cottonseed, soybean hulls, pelleted corn gluten, Nutrimax bypass (vitamin and mineral supplement, QAF Feeds, Corowa, New South Wales, Australia), and cottonseed hulls. The composition of total ration for the TMR and the 5 pasture forage species in this study are listed in Table 1 . The experimental design was a $2 \times$ 2 factorial arrangement of treatments, with 2 breeds (Holstein, Jersey) and 2 feeding systems (TMR, pasture). Feeding system was confounded by herd location because the TMR and PB rations were fed to separate herds at different locations approximately $80 \mathrm{~km}$ apart. However, both herds were state owned, with similar genetics across herds within the 2 breeds.

Milk was collected from each farm in the morning and afternoon milkings on successive days. Fluid milk was collected from farm 1 at the morning milking and farm 2 in the afternoon. The following day, milk was collected from farm 2 in the morning and farm 1 in the afternoon. Milk was collected from 3 to 6 cows within each breed at each sampling. Milking machines were attached to dairy cows and milk was collected from the milk line before flowing into the bulk milk tank. Cows were separated by breed, and the milking lines were cleaned between samples. Milk (38.6 kg) was placed 
Table 1. Formulation and nutrient content of total ration fed to TMR and pasture-based (PB) cows (calculated)

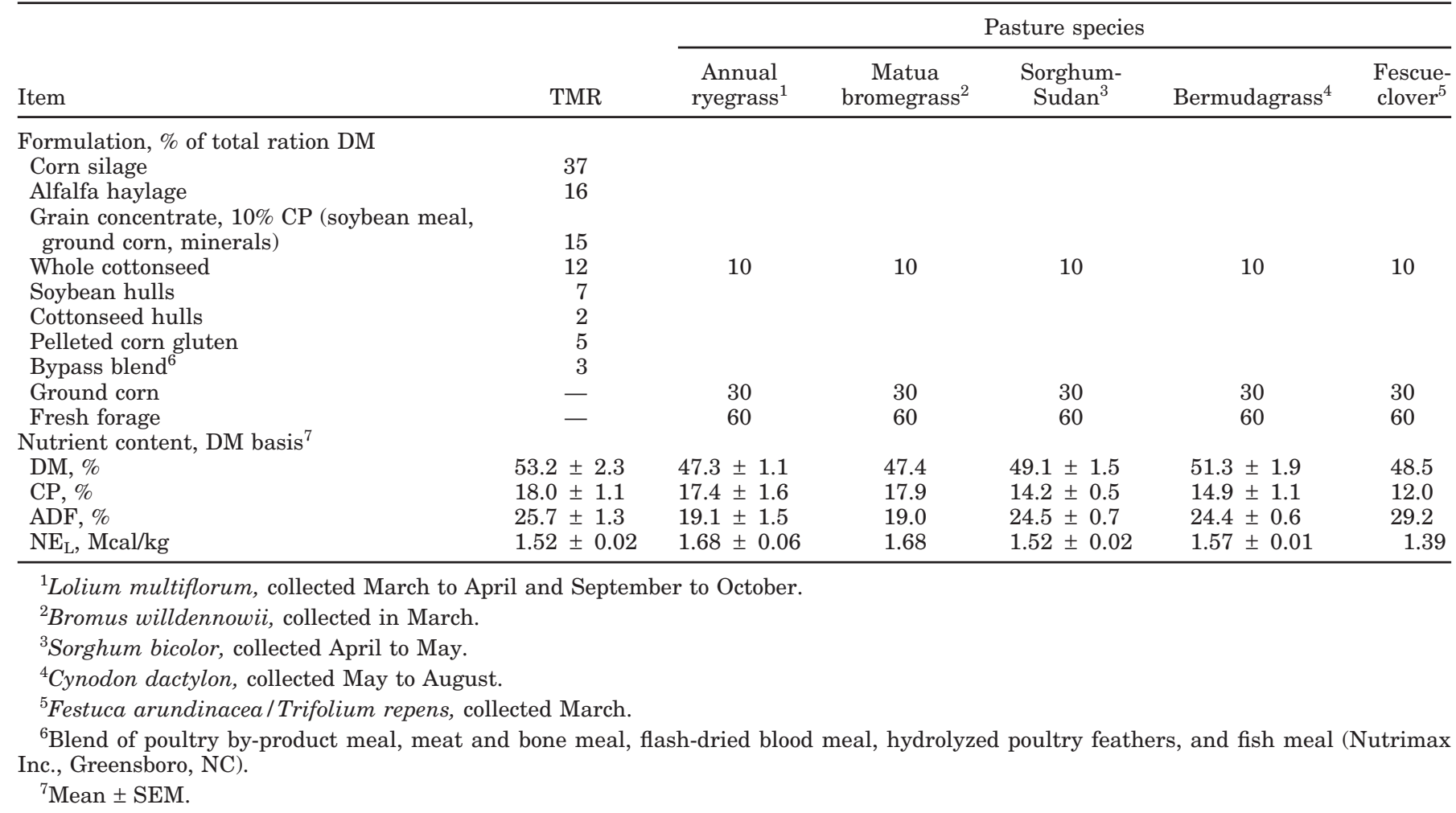

into cleaned and sanitized lidded stainless-steel 38-L cans and packed on ice for transport back to North Carolina State University, Raleigh. Transport time was 20 min for farm 1 and 60 min for farm 2 . The temperature of the milk was $<12^{\circ} \mathrm{C}$ upon arrival at North Carolina State University. Milk was immediately placed at $3^{\circ} \mathrm{C}$ and reached $<5^{\circ} \mathrm{C}$ within $4 \mathrm{~h}$ of collection. Samples $(200 \mathrm{~mL})$ were collected and frozen at $-20^{\circ} \mathrm{C}$ for fatty acid analyses, and similar samples were taken for microbial and compositional analyses. The remaining raw milk was processed within $36 \mathrm{~h}$. A total of 10 collections from each breed at each farm (20 collections total per location) were taken in duplicate from both farms across the 2006 growing season.

\section{Feed Analysis}

Grab samples of pasture were collected randomly from the areas grazed at farm 2 to fill a 3.8-L zipclosure bag. Grab samples were obtained in a manner to simulate the selection of the grazing cow to provide a representative sample. Samples were taken by handtearing the top 7 to $10 \mathrm{~cm}$ of pasture leaves (White et al., 2001). Pasture species were identified on the farm at the time of collection. Table 1 identifies the grass species on which PB cows grazed and the months in which they were collected. Dry samples, consisting of
TMR from farm 1 and ground corn and cottonseed from farm 2, were each placed in zip-closure bags. Feed samples were gathered at each milking and sent to the North Carolina Department of Agriculture and Consumer Services, Food and Drug Protection Division, Forage Laboratory, Raleigh, for protein, moisture, and fiber analysis. Samples were dried in an oven at $80^{\circ} \mathrm{C}$ for a minimum of $15 \mathrm{~h}$. The samples were ground after drying with Retsch ZM 100 and ZM 200 mills with a 1-mm sieve (Arthur H. Thomas Co., Philadelphia, PA). Ground samples were analyzed for CP by Dumas combustion (Leco FP-428, Leco Corporation, St. Joseph, MI) and for ADF by wet chemistry digestion (Ankom 200, Ankom Technology Corp., Fairport, NY). Net energy for lactation was determined by using the Cornell regression equations (Mertens, 1973).

\section{Milk Solids Analysis}

Total solids and fat content of fluid milk were analyzed by using the Smart System 5 moisture/solids analyzer with SmartTrac rapid fat analysis (CEM, Matthews, NC). Solids-not-fat, density, and protein were analyzed by using the LactiCheck ultrasound milk analyzer (P\&P International Ltd., Hopkinton, MA). 


\section{Microbial Analysis}

The Petrifilm plate count method was used to estimate the microbial content in fluid milk samples. Coliform counts and aerobic plate counts were taken for each raw and pasteurized sample by using Petrifilm plastic films (3M, St. Paul, MN) and 0.1\% (wt/wt) peptone water as the diluent. Preliminary incubation counts on raw milk were taken to evaluate sanitary practices at the farm and in processing and handling of the raw milk (Laird et al., 2004). For the preliminary incubation test, raw milk was held at $13^{\circ} \mathrm{C}$ for $18 \mathrm{~h}$ before plating with appropriate dilutions on aerobic plate count Petrifilms.

\section{Fluid Milk Processing}

Raw milk was standardized to $1.5 \%$ milk fat by gravity separation and skimming. The upper milk fat layer was drawn off. The cream and resulting milk were analyzed with the Smart System 5 moisture/solids analyzer with SmartTrac rapid fat analysis (CEM). Cream was added back to the milk by using the Pearson square calculation (Arbuckle, 1977) to reach 1.5\% milk fat. Twenty-five kilograms of fluid milk samples were placed into stainless-steel cans, which were placed into a steam cabinet and batch-pasteurized within $36 \mathrm{~h}$ of collection. Milk was heated to $65.5^{\circ} \mathrm{C}$ with periodic stirring and held for $30 \mathrm{~min}$. Temperature was confirmed throughout the pasteurization period. Samples were then homogenized at $13,600 \mathrm{kPa}(10,150$ first stage, 3,450 second stage) on a Gaulin 300 CGD homogenizer (Boston, MA) and cooled to $5^{\circ} \mathrm{C}$ before refrigeration.

\section{Solid-Phase Microextraction}

Volatile compounds of raw and pasteurized milk were collected by solid-phase microextraction (SPME) and identified by GC-MS. Sample $(20 \mathrm{~g})$ and $\mathrm{NaCl}(2 \mathrm{~g})$ were placed in a $40-\mathrm{mL}$ amber vial with poly(tetrafluoroethylene)/silicone septa (Supelco, Bellefonte, PA) with a stir bar. The internal standard used was 2-methyl-3heptanone at a concentration of $206 \mathrm{mg} / \mathrm{kg}$ (Whetstine et al., 2005). The vial was heated at $40^{\circ} \mathrm{C}$ for $30 \mathrm{~min}$. A 2-cm, 50/30- $\mu \mathrm{m}$ film thickness DVB/Carboxen/PDMS Stableflex SPME fiber (Supelco) was exposed for $60 \mathrm{~min}$ with continuous stirring. Analytes were desorbed onto the column through a splitless injector at $250^{\circ} \mathrm{C}$. Volatile compounds were separated and identified on a Varian (Saturn 2000) mass spectrometer attached to a Varian gas chromatograph (model CP 3380, Varian, Walnut Creek, CA) equipped with a $30-\mathrm{m}, 0.25-\mathrm{mm}$ i.d., $0.25-\mu \mathrm{m}$ film thickness DB-5 column (Restek US, Bellefonte, PA). The oven temperature was held at $40^{\circ} \mathrm{C}$ for $2 \mathrm{~min}$, then increased to $200^{\circ} \mathrm{C}$ at a rate of $10^{\circ} \mathrm{C} /$ min and held for $15 \mathrm{~min}$. Helium was used as a carrier gas at a flow rate of $0.4 \mathrm{~mL} / \mathrm{min}$. The fiber was removed from the injector after $5 \mathrm{~min}$. Relative abundance was calculated by using the peak area of the volatile compound and the peak area and known concentration of the internal standard. Chemical standards (dimethyl sulfide, 2-butanone, acetic acid, 2-pentanone, 3-pentanone, toluene, 2-hexanone, hexanal, butanoic acid, 2furanmethanol, 2-heptanone, heptanal, 3-octenol, octanal, hexanoic acid, limonene, 2-nonanone, nonanal, maltol, octanoic acid, nonanoic acid, 2-undecanone, indole, $n$-decanoic acid, indole, 3 -methyl, $\delta$-decalactone, dodecanoic acid, $\delta$-dodecalactone, tetradecanoic acid, $n$ hexadecanoic acid, oleic acid, octadecanoic acid) were obtained from Supelco.

\section{Fatty Acid Analysis and Color}

Milk fat was extracted from raw milk by using the AOAC choloroform-methanol extraction method for fat in foods (Deutsch, 1990). Fatty acids were methylated with $14 \%$ boron trifluoride in methanol (Bannon et al., 1982) and injected onto a split injector at $220^{\circ} \mathrm{C}$ with a split flow rate of 50:1. Compounds were resolved by using a Perkin-Elmer Autosampler XL gas chromatograph (Wellesley, MA) with an RT-2560 (100 m, 0.25 $\mathrm{mm}$ i.d., $0.2 \mathrm{~mm}$ film thickness) column (Restek) terminating at a flame-ionization detector. The oven temperature was held at $100^{\circ} \mathrm{C}$ for $2 \mathrm{~min}$, then increased to $250^{\circ} \mathrm{C}$ at a rate of $3^{\circ} \mathrm{C} / \mathrm{min}$ and held for $4 \mathrm{~min}$. Helium was used as a carrier gas at a flow rate of $275.8 \mathrm{kPa}$. Fatty acids were identified by comparison of retention times with those of authentic standards (Sigma Aldrich, St. Louis, MO). Color was measured by using a Minolta Chroma meter (CR-300 series) with a DP-301 data processor (Ramsey, NJ). Ten milliliters of raw milk was placed in the top of a Falcon $60 \times 15 \mathrm{~mm}$ polystyrene Petri dish for triplicate measurements. The equipment was calibrated before each session with a factory-supplied calibration plate. The Hunter Lab color scale was used.

\section{Descriptive Sensory Analysis}

All sensory testing was conducted in accordance with the North Carolina State University Institutional Review Board for Human Subjects guidelines. Evaluation of milk flavor was conducted by using a trained descriptive sensory panel and an established flavor language (Table 2). Panelists $(n=10)$ each had more than $100 \mathrm{~h}$ of previous experience with the sensory analysis of dairy products with the Spectrum descriptive analysis method (Meilgaard et al., 1999). Before this study, panelists participated in $20 \mathrm{~h}$ of additional training on or- 
Table 2. Descriptive sensory language for fluid milk

\begin{tabular}{|c|c|c|}
\hline Term & Definition & Reference \\
\hline Cooked $^{1}$ & Aromatics associated with cooked milk & Skim milk heated to $85^{\circ} \mathrm{C}$ for $30 \mathrm{~min}$ \\
\hline Cowy/barny/phenolic ${ }^{1}$ & $\begin{array}{l}\text { Aromas associated with barns and stock trailers, indicative } \\
\text { of animal sweat and waste }\end{array}$ & Band-Aids, $p$-cresol $(160 \mathrm{mg} / \mathrm{kg})$ \\
\hline Mothball $^{1}$ & Aroma associated with complex protein decomposition & Indole, skatole $(20 \mathrm{mg} / \mathrm{kg})$ \\
\hline Sweet $^{2}$ & Fundamental taste sensation elicited by sugars & Sucrose (5\% in water) \\
\hline Salty $^{2}$ & Fundamental taste sensation elicited by sodium salt & Sodium chloride $(0.3 \%$ in water $)$ \\
\hline Astringency $^{2}$ & $\begin{array}{l}\text { Chemical feeling factor on the tongue or oral cavity } \\
\text { described as puckering or dry }\end{array}$ & Alum ( $1 \%$ in water $)$ \\
\hline
\end{tabular}

${ }^{1}$ Reference taken from Drake et al. (2001).

${ }^{2}$ Reference taken from Civille and Lyons (1996).

ganic and reduced-fat fluid milk flavor with the identified sensory language. During training, panelists evaluated and discussed conventional and organic pasteurized and ultrapasteurized milks to ensure panel consistency and understanding of the lexicon. Pasteurized fluid milk (30 mL) was placed in 3-digit-coded, 60-mL lidded cups (Sweetheart Cup Company, Owings Mills, MD). Preparations were conducted with overhead lights off to avoid exposure to light. Samples were prepared $24 \mathrm{~h}$ in advance and refrigerated at $4^{\circ} \mathrm{C}$. Samples were then tempered to $15^{\circ} \mathrm{C}$ before analysis. Samples were evaluated in duplicate on paper ballots by each panelist in a randomized balanced block design.

\section{Difference Testing}

Difference testing was conducted by using a triangle difference test to determine whether consumers could detect differences between fluid milk from conventional and PB systems. Milk from Jersey and Holstein breeds was evaluated individually; difference tests compared feeding systems, not breeds. A total of 40 triangle tests were conducted, representing 20 time points and 2 breeds. Triangle tests were conducted at each collection time point on pasteurized milk. Milks were served at $7^{\circ} \mathrm{C}$ in 3 -digit-coded $180-\mathrm{mL}$ polystyrene cups with opaque lids and straws to ensure that color variation was not a source of difference. Samples were evaluated individually in dedicated sensory booths by using Compusense five, version 4.6, software (Guelph, Ontario, Canada) and presented in a randomized balanced order. Participants ( $\mathrm{n}=50$ at each time) were recruited via e-mail, classified advertisements, and flyers. All participants were screened for allergies to dairy products. Subjects were given ambient-temperature deionized water to cleanse their palates between samples. Demographic information and milk usage information were collected before tasting. Subjects received food treats and a gift card for their participation.

\section{Consumer Acceptance Testing}

Acceptance testing with milk consumers was conducted on different days from difference testing. Selfreported milk consumers were recruited via e-mail, classified advertisements, and flyers. Milk preparation and presentation were identical to those in difference testing. Consumers ( $\mathrm{n}=75$ at each time) were provided with the 4 milks monadically in a randomized balanced order of presentation and were asked to evaluate overall liking, flavor liking, and texture/mouthfeel liking. Attributes were scored on a 9-point hedonic scale, where $1=$ dislike extremely and $9=$ like extremely. Samples were evaluated individually in dedicated sensory booths by using Compusense five, version 4.6.

\section{Statistical Analysis}

Proximate analyses, and sensory and instrumental results were analyzed by using XLSTAT statistical software (version 2006.3, Addinsoft, New York, NY). Twoway ANOVA was conducted to explore the impact of breed and feeding regimen. Fisher's least significant difference was conducted as a post hoc test. A principal components (PC) analysis was also conducted to determine how the treatments (breed, feeding regimen) and individual collections were differentiated from each other across sensory and instrumental measurements.

\section{RESULTS AND DISCUSSION}

\section{Proximate Analysis}

There were no significant interactions between treatment $\times$ breed, breed $\times$ time, or treatment $\times$ time $($ Table 
Table 3. Means of compositional analysis of pasture-based and conventional TMR whole milk by breed and treatment

\begin{tabular}{|c|c|c|c|c|c|c|c|c|}
\hline \multirow[b]{3}{*}{ Item } & \multirow{2}{*}{\multicolumn{2}{|c|}{ Jersey }} & \multirow{2}{*}{\multicolumn{2}{|c|}{ Holstein }} & \multirow[b]{3}{*}{ SEM } & \multicolumn{3}{|c|}{$P$-value } \\
\hline & & & & & & \multirow[b]{2}{*}{ Treatment } & \multirow[b]{2}{*}{ Breed } & \multirow{2}{*}{$\begin{array}{c}\text { Time } \\
\text { (a.m./p.m.) }\end{array}$} \\
\hline & TMR & Pasture & TMR & Pasture & & & & \\
\hline Fat, \% & $4.54^{\mathrm{a}}$ & $4.04^{\mathrm{b}}$ & $3.75^{\mathrm{b}}$ & $3.20^{\mathrm{c}}$ & 0.39 & 0.01 & 0.01 & 0.01 \\
\hline $\mathrm{TS}, \%$ & $13.72^{\mathrm{a}}$ & $13.16^{\mathrm{b}}$ & $12.43^{\mathrm{c}}$ & $11.85^{\mathrm{d}}$ & 0.48 & 0.01 & 0.01 & NS \\
\hline Protein, \% & $3.64^{\mathrm{a}}$ & $3.63^{\mathrm{a}}$ & $3.49^{\mathrm{b}}$ & $3.49^{\mathrm{b}}$ & 0.05 & $\mathrm{NS}^{1}$ & 0.01 & NS \\
\hline $\mathrm{SNF}, \%$ & $9.59^{\mathrm{a}}$ & $9.58^{\mathrm{a}}$ & $9.21^{\mathrm{b}}$ & $9.23^{\mathrm{b}}$ & 0.13 & NS & 0.01 & NS \\
\hline Density, g/cm & $1.0318^{\mathrm{a}}$ & $1.0322^{\mathrm{a}}$ & $1.0310^{\mathrm{b}}$ & $1.0316^{\mathrm{ab}}$ & 0.001 & NS & 0.01 & 0.01 \\
\hline \multicolumn{9}{|l|}{ Hunter color } \\
\hline $\mathrm{L}$ & $89.06^{\mathrm{a}}$ & $88.23^{\mathrm{a}}$ & $88.94^{\mathrm{a}}$ & $87.93^{\mathrm{a}}$ & 4.46 & NS & NS & NS \\
\hline $\mathrm{a}$ & $-1.80^{\mathrm{ab}}$ & $-2.37^{b}$ & $-0.89^{\mathrm{a}}$ & $-1.60^{\mathrm{ab}}$ & 0.92 & NS & NS & NS \\
\hline $\mathrm{b}$ & $5.32^{\mathrm{a}}$ & $7.34^{\mathrm{a}}$ & $2.07^{\mathrm{c}}$ & $3.85^{\mathrm{bc}}$ & 1.75 & 0.05 & 0.01 & NS \\
\hline
\end{tabular}

${ }^{\mathrm{a}-\mathrm{d}}$ Means within rows with different superscripts are different $(P<0.05)$.

${ }^{1} \mathrm{NS}(P>0.05)$.

3). By the Hunter Lab color scale, the milks were differentiated by breed $(P<0.01)$ and treatment $(P<0.05)$ on the $b$ axis. A positive value on the $b$ axis represents a more yellow color. A more yellow color in PB milks is expected because cows ingest fresh forage, which raises the concentration of carotenoids in milk fat (Kosikowski and Mistry, 1997; Hulshof et al., 2006). $\beta$-Carotene serves as the primary carotenoid contributing to the color of milk fat (Panfili et al., 1994).

Milk collection time differentiated the milks by milk fat $(P<0.01)$ and density $(P<0.01)$. Milk collected in the morning was denser $(1.0320$ vs. $1.0313 \mathrm{~g} / \mathrm{cm})$ than milk collected in the afternoon. Milk collected in the afternoon contained a greater milk fat content (4.09 to $3.68 \%$ ) compared with milk collected in the morning. Differences in both density and milk fat can be attributed to the longer time between the afternoon and morning milkings on both farms. Longer intervals between milking produce a lower milk fat content (Ayadi et al., 2004). An increase in milk fat concentration is expected to decrease the density of the milk. Milk fat content was also differentiated by breed $(P<0.01)$ and treatment $(P<0.01)$. In previous studies, greater values have been observed for milk fat and percentage of protein in Jersey cows than in Holstein cows (White et al., 2001). Pasture-fed cows produced milk with lower milk fat and TS contents $(P<0.01)$, consistent with previous studies (White et al., 2001; Bargo et al., 2002).

\section{Fatty Acids}

Table 4 summarizes fatty acid concentrations by the percentage of total fatty acids. Significant differences $(P<0.01)$ were observed in the percentages of saturated, unsaturated, and monounsaturated fatty acids by breed and treatment. Pasture-based milk contained higher concentrations of CLA and a lower ratio of saturated:unsaturated fatty acids. Conjugated linoleic acid is a mixture of octadecanoic acid isomers with 2 conjugated double bonds. The main CLA component of milk fat is the cis-9, trans-11 isomer, representing 75 to $90 \%$ of the total CLA (Chin et al., 1992). Feed has been shown to have a significant effect on milk fat composition (Bauman et al., 2001; Ellis et al., 2006). The PB milks analyzed in the current study contained nearly $60 \%$ greater CLA concentration and $45 \%$ more trans11 18:1, a CLA intermediate (Griinari et al., 1999) that has been linked to higher levels of CLA upon ingestion (Banni et al., 2001). Pasture-based milks had a lower ratio of saturated:unsaturated fatty acids ( $1.70 \mathrm{vs.} 2.05$; $P<0.01$ ). This result was consistent with previous work comparing PB and TMR milks (Schroeder et al., 2005). Saturated fatty acids have been associated with an increased risk of coronary heart disease (Hu et al., 1999), making the lower ratio of saturated:unsaturated fatty acids in PB milk more beneficial for health. Levels of monounsaturated fatty acids showed significant differences by breed $(P<0.01)$ and treatment $(P<0.01)$. Milk from pasture-grazing cows was 3 percentage points higher in monunsaturated fatty acids than TMR milk, an increase of $10 \%$. In addition, PB milk was 0.5 percentage points higher in polyunsaturated fatty acids compared with TMR milk, which corresponds to the findings by Ellis et al. (2006).

\section{Volatile Compounds}

Figure 1 presents a PC analysis biplot of 32 volatile compounds identified in both PB and TMR milks. Principal components 1 and 2 accounted for $80.6 \%$ of the variability between samples. Table 5 shows the compound concentrations calculated by relative abundance in relation to an internal standard. No compounds were unique to either breed or feeding regimen, in agreement with the findings of Bendall (2001). Using solvent-assisted flavor evaporation with nasal impact frequency, 
Table 4. Means for fatty acid composition (\% of total fatty acids) by treatment and breed group

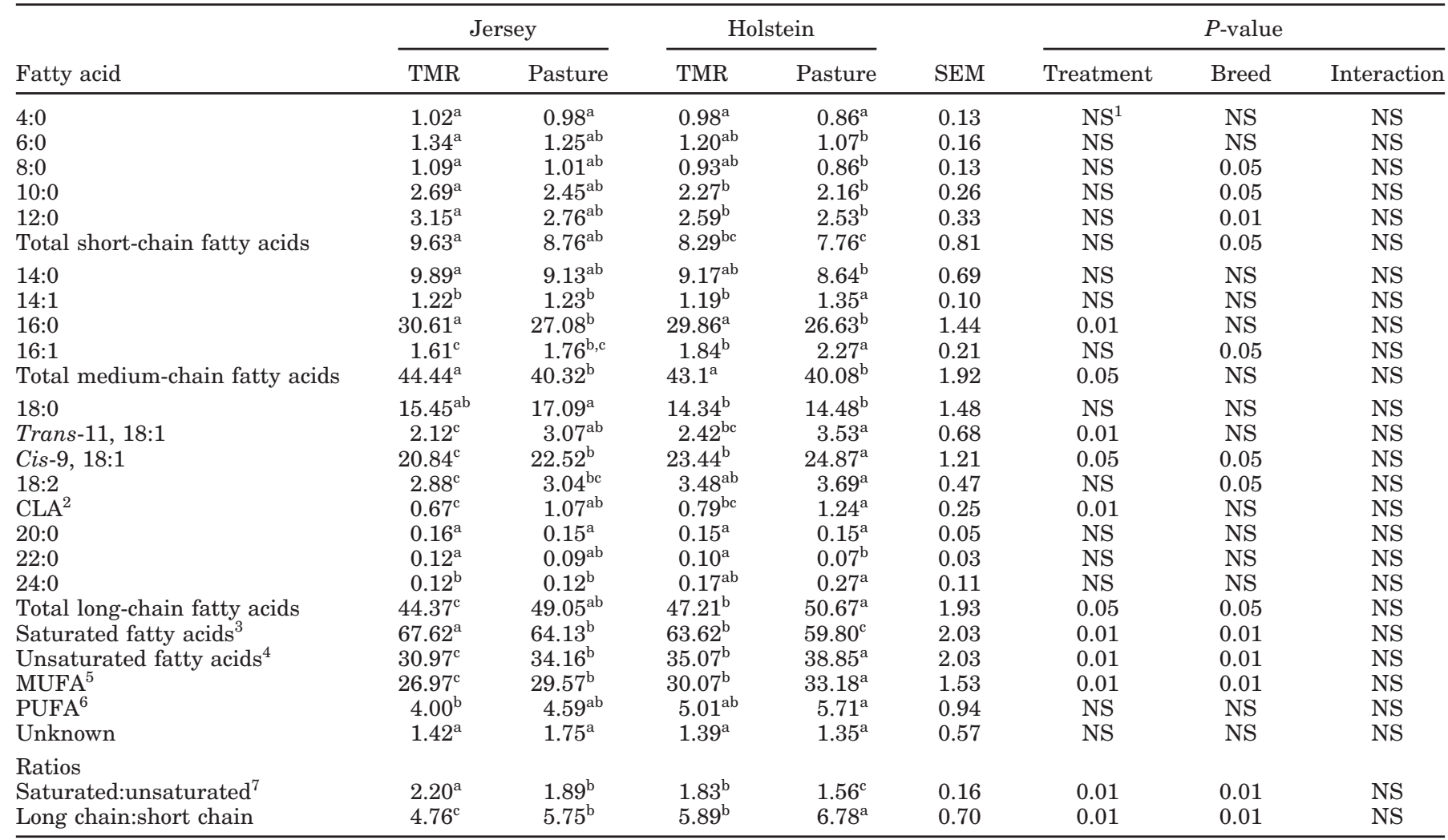

${ }^{\mathrm{a}-\mathrm{c}}$ Means within rows with different superscripts are different $(P<0.05)$.

${ }^{1} \mathrm{NS}(P>0.05)$.

${ }^{2}$ Conjugated linoleic acid (CLA): cis-9, trans-11 and trans-10, cis-12 18:2 isomers only.

${ }^{3}$ Saturated fatty acids: sum of 4:0, 5:0, 6:0, 8:0, 10:0, 11:0, 12:0, 13:0, 14:0, 15:0, 16:0, 17:0, 18:0, 19:0, 20:0, 22:0, 23:0, and 24:0 fatty acids.

${ }^{4}$ Unsaturated fatty acids: sum of 10:1, 12:1, 13:1, 14:1, 15:1, 16:1, 17:1, 18:1, 20:1, 22:1, 18:2, 18:3, and 20:4 fatty acids.

${ }^{5}$ Monounsaturated fatty acids (MUFA): sum of 10:1, 12:1, 13:1, 14:1, 15:1, 16:1, 17:1, 18:1, 20:1, 22:1, and 24:1 fatty acids.

${ }^{6}$ Polyunsaturated fatty acids (PUFA): sum of 18:2, 18:3, and 20:4 fatty acids.

${ }^{7}$ Ratio of saturated fatty acids:unsaturated fatty acids.

Bendall (2001) compared PB and TMR milks and found that of the 71 compounds identified by gas chromatography-olfactometry, only one compound was unique, $\gamma$ 12:2 lactone. Production of this compound has been associated with microbial activity (Haffner et al., 1996). Compounds identified and classified by chemical class were 11 carboxylic acids, 6 ketones, 4 aldehydes, 3 aromatic hydrocarbons, 2 lactones, 2 nitrogen compounds, 2 lactones, 1 terpene, 1 alcohol, and 1 sulfur compound.

Indole and skatole have been associated with the flavor of PB milk (Urbach, 1990; Bendall, 2001). The SPME method used in this research did not extract indole at levels sufficient to separate TMR and PB milks. However, skatole was present in higher levels in the PB milks. Drake et al. (2007) explored the mothball/ grassy flavor in Cheddar cheese. These researchers were able to simulate a mothball flavor through additions of acetic acid, 2-methyl butanoic acid, 3-methyl indole (skatole), methional, and $o$-aminoacetophenone to mild Cheddar cheese without the mothball/grassy flavor. However, based on the overall similarity to the mothball/grassy cheeses, the researchers concluded that other compounds also potentially contributed to this flavor. In the current study, methional, 2-methyl butanoic acid, and $o$-aminoacetophenone were below instrumental detection limits.

\section{Descriptive Analysis}

Significant differences were noted in the flavor profiles of the milk from the 2 different feeding systems (Table 6 and Figure 2), similar to the volatile compound differences. No significant differences were found for breed or for a treatment-by-breed interaction in any of the attributes tested. Conventional milk was characterized by a sweet feed/malty flavor, a greater sweet aro- 


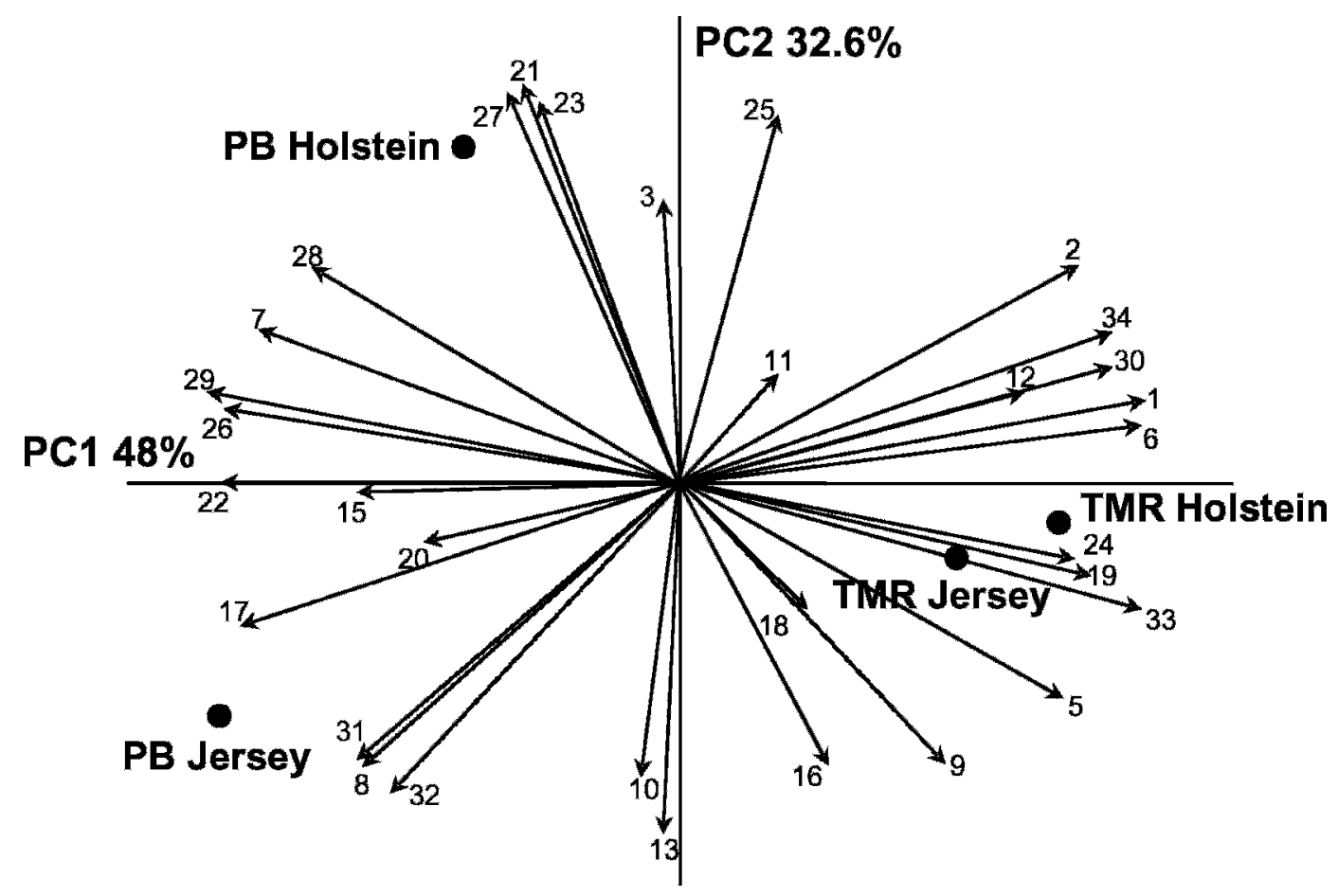

Figure 1. Principal components biplot of fluid milk volatile compounds from pasture-based (PB) and TMR feeding systems. Compounds (Table 5) are overlaid as vectors.

matic flavor, and a sweet taste, but no grassy or mothball flavors, compared with PB milks. Milk from grazing cows was characterized by a low but distinct salty taste and by grassy and mothball flavors. As shown in the PC biplot (Figure 2), the PB and TMR milks were clearly differentiated along PC1. The PB milks fell near the vectors for grassy, mothball, and salty tastes, whereas the TMR milks fell near the vectors representing feed/ malty, sweet taste, and sweet aromatic. Principal components 1 and 2 accounted for $98 \%$ of the variability in the milks.

A search of the literature revealed no previous research comparing the flavor of PB milk with conventional milk by descriptive analysis. Numerous studies have been performed comparing the volatile fraction of milk from cows consuming varying feeds (Bendall, 2001; Bugaud et al., 2001; Toso et al., 2002), as well as the volatile fraction of cheese (Buchin et al., 1998; Carpino et al., 2004). Drake et al. (2005) reported that Cheddar cheeses from New Zealand were characterized by grassy and mothball flavors compared with cheeses from the United States and Ireland. They hypothesized that this distinct flavor was due to the PB dairy industry in New Zealand.

In the current study, trained panelists were able to differentiate milks by feeding regimen. We found no previous attempt to relate a sensory analysis to the flavor compounds identified in fluid milk from cows consuming different feed types. Fillian and Arazi (2002) attempted to compare several commercial organic and conventional milks by descriptive analysis, although they were unable to differentiate the samples based on sensory characteristics. For milks, few statistical differences were found, with no distinct grouping of milks. Organic milk is not defined by the composition of the feed, but rather the origin and production processes. It is not a requirement in the United States (USDA, 2006) or the European Union (Department for Environment, Food and Rural Affairs, Organic Branch, 2006) that organic cows be fed a PB diet alone, although access to pasture is required during the grazing seasons.

\section{Consumer Difference and Acceptance Testing}

A total of 20 separate triangle tests were conducted for each breed, representing each collection time point. Consumers were able to distinguish the different samples with significance $(P<0.05)$ on only 7 occasions (35\% of total tests) when comparing milk from TMR Jersey cows with PB Jersey cows. Similarly, when comparing TMR Holstein milk with PB Holstein milk, consumers were able to distinguish the different samples with significance $(P<0.05)$ on only 7 occasions, but not 
Table 5. Mean relative abundance ( $\mathrm{mg} / \mathrm{kg}, \pm \mathrm{SEM})$ for selected volatile compounds in fluid milk from pasturebased and TMR feeding systems

\begin{tabular}{|c|c|c|c|c|c|}
\hline \multirow[b]{2}{*}{ Compound } & \multirow[b]{2}{*}{ Treatment } & \multicolumn{2}{|c|}{ Jersey } & \multicolumn{2}{|c|}{ Holstein } \\
\hline & & TMR & Pasture & TMR & Pasture \\
\hline Dimethyl sulfide & Compound 1 & $2.26 \pm 1.27$ & $1.03 \pm 0.72$ & $2.42 \pm 1.67$ & $0.72 \pm 0.48$ \\
\hline 2-Butanone & Compound 2 & $11.35 \pm 8.62$ & $4.33 \pm 2.36$ & $12.26 \pm 9.11$ & $5.72 \pm 3.19$ \\
\hline Acetic acid & Compound 3 & $0.53 \pm 0.31$ & $1.89 \pm 3.55$ & $4.27 \pm 6.51$ & $4.71 \pm 5.19$ \\
\hline 2-Pentanone & Compound 5 & $1.32 \pm 0.78$ & $1.10 \pm 0.55$ & $1.45 \pm 1.15$ & $0.86 \pm 0.32$ \\
\hline 3-Pentanone & Compound 6 & $0.54 \pm 0.29$ & $0.19 \pm 0.12$ & $0.48 \pm 0.25$ & $0.22 \pm 0.14$ \\
\hline Toluene & Compound 7 & $0.68 \pm 0.27$ & $2.28 \pm 1.38$ & $0.82 \pm 0.72$ & $2.52 \pm 1.35$ \\
\hline 2-Hexanone & Compound 8 & $0.50 \pm 0.03$ & $0.09 \pm 0.05$ & $0.06 \pm 0.03$ & $0.06 \pm 0.03$ \\
\hline Hexanal & Compound 9 & $0.35 \pm 0.22$ & $0.27 \pm 0.15$ & $0.28 \pm 0.14$ & $0.19 \pm 0.10$ \\
\hline Butanoic acid & Compound 10 & $0.44 \pm 0.32$ & $0.51 \pm 0.31$ & $0.51 \pm 0.41$ & $0.43 \pm 0.23$ \\
\hline 2-Furanmethanol & Compound 11 & $3.16 \pm 3.15$ & $5.76 \pm 5.05$ & $10.71 \pm 7.28$ & $7.47 \pm 5.12$ \\
\hline 2-Heptanone & Compound 12 & $2.27 \pm 1.08$ & $1.74 \pm 0.57$ & $1.96 \pm 0.69$ & $1.84 \pm 0.55$ \\
\hline Heptanal & Compound 13 & $0.14 \pm 0.09$ & $0.14 \pm 0.01$ & $0.12 \pm 0.10$ & $0.10 \pm 0.07$ \\
\hline 3-Octenol & Compound 14 & $1.79 \pm 0.66$ & $1.86 \pm 0.59$ & $0.76 \pm 0.34$ & $1.72 \pm 0.64$ \\
\hline Octanal & Compound 15 & $0.10 \pm 0.06$ & $0.11 \pm 0.08$ & $0.11 \pm 0.08$ & $0.09 \pm 0.06$ \\
\hline Hexanoic acid & Compound 16 & $0.67 \pm 0.40$ & $1.75 \pm 1.34$ & $0.64 \pm 0.61$ & $1.03 \pm 0.86$ \\
\hline D-Limonene & Compound 17 & $0.56 \pm 0.41$ & $0.45 \pm 0.23$ & $0.41 \pm 0.17$ & $0.39 \pm 0.15$ \\
\hline 2-Nonanone & Compound 18 & $0.96 \pm 0.74$ & $0.63 \pm 0.43$ & $0.84 \pm 0.67$ & $0.64 \pm 0.39$ \\
\hline Nonanal & Compound 19 & $0.51 \pm 0.39$ & $0.62 \pm 0.41$ & $0.60 \pm 0.71$ & $0.58 \pm 0.68$ \\
\hline Maltol & Compound 20 & $0.62 \pm 0.61$ & $1.09 \pm 1.42$ & $1.37 \pm 1.94$ & $1.35 \pm 1.78$ \\
\hline Octanoic acid & Compound 21 & $1.85 \pm 1.50$ & $2.87 \pm 3.15$ & $1.22 \pm 0.81$ & $1.93 \pm 1.22$ \\
\hline Nonanoic acid & Compound 22 & $0.20 \pm 0.13$ & $0.23 \pm 0.16$ & $0.27 \pm 0.23$ & $0.39 \pm 0.29$ \\
\hline 2-Undecanone & Compound 23 & $0.89 \pm 0.73$ & $0.76 \pm 0.55$ & $1.22 \pm 1.12$ & $0.74 \pm 0.36$ \\
\hline Indole & Compound 24 & $0.09 \pm 0.03$ & $0.02 \pm 0.01$ & $\mathrm{ND}^{1}$ & $0.13 \pm 0.06$ \\
\hline$n$-Decanoic acid & Compound 25 & $5.21 \pm 3.45$ & $6.91 \pm 6.09$ & $4.21 \pm 2.99$ & $4.92 \pm 2.80$ \\
\hline Skatole & Compound 26 & $0.24 \pm 0.18$ & $0.32 \pm 0.17$ & $0.33 \pm 0.26$ & $0.39 \pm 0.23$ \\
\hline$\delta$-Decalactone & Compound 27 & $0.28 \pm 0.21$ & $0.29 \pm 0.19$ & $0.26 \pm 0.17$ & $0.31 \pm 0.17$ \\
\hline Dodecanoic acid & Compound 28 & $1.49 \pm 0.71$ & $1.84 \pm 1.26$ & $1.36 \pm 1.18$ & $1.23 \pm 0.75$ \\
\hline$\delta$-Dodecalactone & Compound 29 & $0.28 \pm 0.22$ & $0.15 \pm 0.09$ & $0.37 \pm 0.26$ & $0.16 \pm 0.11$ \\
\hline Tetradecanoic acid & Compound 30 & $4.00 \pm 3.32$ & $9.52 \pm 8.25$ & $4.18 \pm 4.05$ & $2.41 \pm 1.96$ \\
\hline$n$-Hexadecanoic acid & Compound 31 & $7.02 \pm 6.94$ & $3.51 \pm 3.02$ & $8.63 \pm 7.97$ & $4.13 \pm 3.36$ \\
\hline Oleic acid & Compound 32 & $2.08 \pm 1.35$ & $0.97 \pm 0.65$ & $2.16 \pm 1.64$ & $0.87 \pm 0.59$ \\
\hline Octadecanoic acid & Compound 33 & $8.08 \pm 6.02$ & $3.57 \pm 3.08$ & $10.32 \pm 8.35$ & $7.03 \pm 5.56$ \\
\hline
\end{tabular}

${ }^{1} \mathrm{ND}=$ not detected.

usually the same occasions as for Jersey milk. Therefore, the ability to distinguish differences was not affected by collection date. Annual ryegrass and bermudagrass species were positively identified more often than other pasture species, but those 2 species also comprised 14 of the 20 collections. No distinct seasonal tendencies were associated with the ability of consumers to differentiate the samples, nor did any time-related trend indicate that panelists became more sensitive with testing experience. No relation was found between the positively identified samples from the difference tests and the subsequent acceptance testing performed the next day.

The ability to differentiate milks did not have a significant effect $(P<0.05)$ on the hedonic scores. There were no significant differences $(P<0.05)$ in overall liking and texture liking among the 4 milks (Table 7). Pasture-based Holstein milk scored significantly lower in flavor liking than TMR Holstein milk (5.88 vs. 6.12; $P<0.05$ ), but was not different from PB Jersey and TMR Jersey milk. Although there were no significant differences between the intensities of grassy and moth- ball flavors by trained panel profiles, PB Holstein milk had higher intensities ( 0.2 points in both attributes) of these attributes compared with PB Jersey milk, and perhaps this contributed to lower flavor liking scores from consumers. It should be noted that a lower flavor liking score did not have a significant effect on the overall liking scores of PB Holstein milk. Sensory scores for all milk samples fell within a normal range relative to previous research.

One objective of this study was to determine the effects of a PB feeding system on the consumer acceptance of fluid milk. The current results show that the consumer was unable to routinely identify differences between samples. Furthermore, distinct differences documented by trained panelists (grassy and mothball flavors in PB milk and feed/malty flavors in PB milks) did not have an effect on overall consumer liking. Differences noted by trained panelists are not always detected by untrained consumers. Further, sensory differences may exist but may not affect consumer acceptance. Trained panel profiling was conducted at $15^{\circ} \mathrm{C}$ to maximize panelists' ability to discern milk flavors. In con- 
Table 6. Sensory profiles of $1.5 \%$ pasteurized milk from pasture-based and TMR feeding systems for each treatment and breed group ${ }^{1}$

\begin{tabular}{|c|c|c|c|c|c|c|c|c|}
\hline \multirow[b]{2}{*}{ Sensory attribute $^{2}$} & \multicolumn{2}{|c|}{ Jersey } & \multicolumn{2}{|c|}{ Holstein } & \multirow[b]{2}{*}{ SEM } & \multicolumn{3}{|c|}{$P$-value } \\
\hline & TMR & Pasture & TMR & Pasture & & Treatment & Breed & Interaction \\
\hline Aroma intensity & $2.02^{\mathrm{a}}$ & $1.99^{\mathrm{a}}$ & $2.02^{\mathrm{a}}$ & $1.99^{\mathrm{a}}$ & 0.20 & $\mathrm{NS}^{3}$ & NS & NS \\
\hline Sweet aromatic & $2.46^{\mathrm{a}}$ & $1.97^{\mathrm{b}}$ & $2.42^{\mathrm{a}}$ & $1.85^{\mathrm{b}}$ & 0.25 & 0.01 & NS & NS \\
\hline Cooked & $2.80^{\mathrm{a}}$ & $2.76^{\mathrm{a}}$ & $2.82^{\mathrm{a}}$ & $2.72^{\mathrm{a}}$ & 0.22 & NS & NS & NS \\
\hline Milk fat & $2.11^{\mathrm{a}}$ & $2.06^{\mathrm{a}}$ & $2.11^{\mathrm{a}}$ & $2.06^{\mathrm{a}}$ & 0.13 & NS & NS & NS \\
\hline Grassy & $\mathrm{ND}^{4}$ & $1.26^{\mathrm{a}}$ & ND & $1.47^{\mathrm{a}}$ & 0.35 & 0.01 & NS & NS \\
\hline Mothball & ND & $1.05^{\mathrm{a}}$ & ND & $1.23^{\mathrm{a}}$ & 0.39 & 0.01 & NS & NS \\
\hline Sweet & $2.36^{\mathrm{a}}$ & $2.14^{\mathrm{b}}$ & $2.38^{\mathrm{a}}$ & $1.97^{\mathrm{c}}$ & 0.18 & 0.01 & NS & NS \\
\hline Sweet feed/malty & $1.91^{\mathrm{a}}$ & ND & $1.88^{\mathrm{a}}$ & ND & 0.52 & 0.01 & NS & NS \\
\hline Astringency & $1.06^{\mathrm{a}}$ & $1.07^{\mathrm{a}}$ & $1.02^{\mathrm{a}}$ & $1.06^{\mathrm{a}}$ & 0.09 & NS & NS & NS \\
\hline Salty & ND & $0.86^{\mathrm{a}}$ & ND & $1.01^{\mathrm{a}}$ & 0.41 & 0.01 & NS & NS \\
\hline
\end{tabular}

${ }^{\mathrm{a}-\mathrm{c}}$ Means within rows with different superscripts are different $(P<0.05)$.

${ }^{1}$ Scores based on a universal 15-point intensity scale.

${ }^{2}$ Means are from duplicate analyses by 10 trained panelists.

${ }^{3} \mathrm{NS}(P>0.05)$.

${ }^{4} \mathrm{ND}=$ not detected.

trast, difference and consumer testing were conducted at $7^{\circ} \mathrm{C}$, which is a temperature at which consumers normally consume milk. The lower temperature may have masked flavor differences because of decreased volatility of compounds, and this may also explain the lack of difference and the lack of difference in acceptance.

Khanal et al. (2005) compared milk and cheese produced by TMR, pasture feeding, and TMR plus pasture feeding regimens by using acceptance testing with panelists that had previous experience in dairy judging and grading. No significant differences were reported in overall liking, color, flavor, or mouthfeel for milk or cheese. Panelists were given chemical references with limited training (2 sessions) on the use of a cheese flavor language. Panelists identified differences in the milks, with the pasture and pasture plus TMR products scoring higher in cowy and barny attributes. These results are consistent with the results of this study; however, a direct comparison cannot be made because panelists were essentially untrained and different scaling was used.

Debate continues over the nutritional, compositional, and sensory properties of organic vs. conventional foods. Much of the focus has concentrated on produce and grains. Bourn and Prescott (2002) discussed 209 arti-

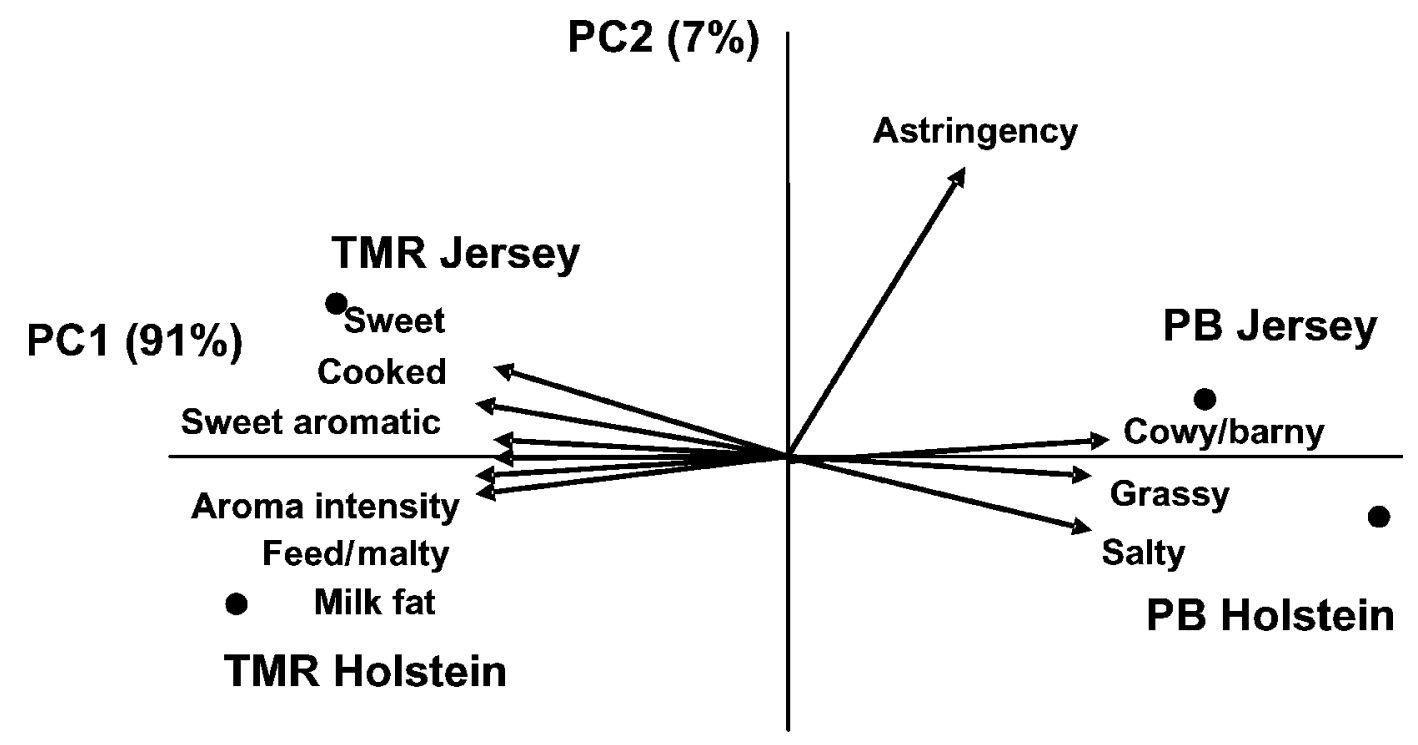

Figure 2. Principal components biplot of descriptive sensory analysis of fluid milk from pasture-based (PB) and TMR-fed cows. Sensory attributes are overlaid as vectors. 
Table 7. Consumer acceptance scores for fluid milks from pasture-based and TMR feeding systems by breed and treatment ${ }^{1}$

\begin{tabular}{|c|c|c|c|c|c|c|c|c|}
\hline \multirow[b]{2}{*}{ Item } & \multicolumn{2}{|c|}{ Jersey } & \multicolumn{2}{|c|}{ Holstein } & \multirow[b]{2}{*}{ SEM } & \multicolumn{3}{|c|}{$P$-value } \\
\hline & TMR & Pasture & TMR & Pasture & & Treatment & Breed & Interaction \\
\hline Overall liking & $6.03^{\mathrm{a}}$ & $6.14^{\mathrm{a}}$ & $6.19^{\mathrm{a}}$ & $6.02^{\mathrm{a}}$ & 0.85 & $\mathrm{NS}^{2}$ & NS & 0.01 \\
\hline Flavor liking & $5.96^{\mathrm{ab}}$ & $6.04^{\mathrm{ab}}$ & $6.12^{\mathrm{a}}$ & $5.88^{\mathrm{b}}$ & 0.91 & NS & NS & 0.01 \\
\hline Texture/mouthfeel liking & $6.39^{\mathrm{a}}$ & $6.49^{\mathrm{a}}$ & $6.47^{\mathrm{a}}$ & $6.45^{\mathrm{a}}$ & 0.74 & NS & NS & NS \\
\hline
\end{tabular}

${ }^{\mathrm{a}, \mathrm{b}}$ Means within rows with different superscripts are statistically different $(P<0.05)$

${ }^{1}$ Scores are based on a 9 -point hedonic scale, where $1=$ dislike extremely and $9=$ like extremely.

${ }^{2} \mathrm{NS}(P>0.05)$.

cles comparing the nutritional value, sensory quality, and food safety of organic and conventional food production systems. Although there are reports that organic products maintain superior sensory quality over conventionally produced food, results are inconsistent. Results are convoluted by several factors, including the application of a wide range of methods and study durations, variance in definitions of terms such as "organic" and "quality," and lack of proper controls for direct comparison (Yiridoe et al., 2005). An important consideration when comparing animal products from organic and conventional systems is the source of feed. The current study represents the flavor profile expected from fluid milk produced on a PB dairy farm with feeding practices similar to a certified organic farm as well as processing conditions similar to those of conventional milk. Currently, the majority of organic milk sold in the United States is ultrapasteurized, resulting in a different flavor profile compared with conventional milk.

\section{CONCLUSIONS}

Milks from pasture-fed cows and from cows fed a TMR diet were differentiated by descriptive sensory analysis, proximate analysis, and volatile compound profiles. Milks were not consistently differentiated by difference testing or by consumer acceptance scores. This study demonstrates that the 2 feeding regimens were not a factor in the consumer acceptance of fluid milk flavor. Although many factors are responsible for the increasing demand for organic dairy products, flavor and nutrition are consistently given as significant reasons for the purchase of organic foods. With higher CLA and unsaturated fatty acid concentrations and lower saturated fatty acid concentration, PB milk may provide a better nutritional profile than TMR milk. In addition, this study shows that a PB feeding system for the production of fluid milk does not adversely affect consumer acceptance.

\section{ACKNOWLEDGMENTS}

This is manuscript FSR 07-15 of the journal series of the Department of Food Science, North Carolina State University. The use of trade names does not imply endorsement or criticisms of ones not mentioned.

\section{REFERENCES}

Arbuckle, W. S. 1977. Calculation of ice cream mixes. Pages 135-171 in Ice Cream. 3rd ed. AVI Publishing, Westport, CT.

Ayadi, M., G. Caja, X. Such, M. Rovai, and E. Albanell. 2004. Effect of different milking intervals on the composition of cisternal and alveolar milk in dairy cows. J. Dairy Res. 71:304-310.

Banni, S., E. Angioni, E. Murru, G. Carta, M. P. Melis, D. Bauman, Y. Dong, and C. Ip. 2001. Vaccenic acid feeding increases tissue levels of conjugated linoleic acid and suppresses development of premalignant lesions in rat mammary gland. Nutr. Cancer 41:91-97.

Bannon, C. D., J. D. Craske, N. T. Hai, N. L. Harper, and K. L. O'Rourke. 1982. Analysis of fatty acid methyl esters with high accuracy and reliability. II. Methylation of fats and oils with boron trifluoride-methanol. J. Chromatogr. 247:63-69.

Bargo, F., L. D. Muller, J. E. Delahoy, and J. W. Cassidy. 2002. Performance of high-producing dairy cows with three different feeding systems combining pasture and total mixed rations. J. Dairy Sci. 85:2948-2963.

Bauman, D. E., B. A. Corl, L. H. Baumgard, and J. M. Griinari. 2001. Conjugated linoleic acid (CLA) and the dairy cow. Recent Adv. Anim. Nutr. 221:221-250.

Bendall, J. G. 2001. Aroma compounds of fresh milk from New Zealand cows fed different diets. J. Agric. Food Chem. 49:4825-4832.

Blayney, D. P. 2002. The Changing Landscape of U.S. Milk Production. Stat. Bull. 978. USDA, Econ. Res. Serv., Washington, DC.

Bourn, D., and J. Prescott. 2002. A comparison of the nutritional value, sensory qualities, and food safety of organically and conventionally produced foods. Crit. Rev. Food Sci. Nutr. 42:1-34.

Buchin, S., V. Delague, G. Duboz, J. L. Berdague, E. Beuvier, S. Pochet, and R. Grappin. 1998. Influence of pasteurization and fat composition of milk on the volatile compounds and flavor characteristics of a semi-hard cheese. J. Dairy Sci. 81:3097-3108.

Bugaud, C., S. Buchin, J. Coulon, A. Hauway, and D. Dupont. 2001. Influence of the nature of alpine pastures on plasmin activity, fatty acid and volatile compound composition of milk. Lait 81:401-414.

Buragas, A. 2005. Organic dairy demand exceeds supply; new farmers needed. Cheese Market News 25:1, 12.

Carpino, S., S. Mallia, S. La Terra, C. Melilli, G. Licitra, T. E. Acree, D. M. Barbano, and P. J. Van Soest. 2004. Composition and aroma compounds of Ragusano cheese: Native pasture and total mixed rations. J. Dairy Sci. 87:816-830. 
Chin, S. F., W. Liu, J. M. Storkson, Y. L. Ha, and M. W. Pariza. 1992. Dietary sources of conjugated dienoic acid isomers of linoleic acid, a newly recognized class of anticarcinogens. J. Food Comp. Anal. 5:185-197.

Civille, G. V., and B. G. Lyons. 1996. Aroma and flavor lexicon for sensory evaluation: Terms, definitions, references, and examples. ASTM Data Series Publ. DS 66. ASTM, West Conshohocken, PA.

Department for Environment, Food and Rural Affairs, Organic Branch. 2006. Compendium of UK Organic Standards. Dept. for Environ., Food and Rural Affairs, Organic Branch, London, UK.

Deutsch, M. 1990. Vitamins and other nutrients. Pages 1045-1114 in Official Methods of Analysis. 15th ed. K. Helrich, ed. Assoc. Offic. Anal. Chem., Arlington, VA.

Dhiman, T. R., G. R. Anand, L. D. Satter, and M. W. Pariza. 1999. Conjugated linoleic acid content of milk from cows fed different diets. J. Dairy Sci. 82:2146-2156.

Drake, M. A., K. R. Cadwallader, and M. E. Carunchia Whetstine. 2007. Establishing links between sensory and instrumental analyses of dairy flavors: Example Cheddar cheese. Pages 51-78 in Flavor of Dairy Products. ACS Symp. Ser. 971. K. R. Cadwallader, M. A. Drake, and R. J. McGorrin, ed. Am. Chem. Soc., Washington, DC.

Drake, M. A., M. D. Keziah, P. D. Gerard, C. M. Delahunty, C. Sheehan, R. P. Turnbull, and T. M. Dodds. 2005. Comparison of differences between lexicons for descriptive analysis of Cheddar cheese flavor in Ireland, New Zealand, and the United States. Int. Dairy J. 15:473-483.

Drake, M. A., S. C. McIngvale, P. D. Gerard, K. R. Cadwallader, and G. V. Civille. 2001. Development of a descriptive language for Cheddar cheese. J. Food Sci. 66:1422-1427.

Ellis, K. A., G. Innocent, D. Grove-White, P. Cripps, W. G. McLean, C. V. Howard, and M. Mihm. 2006. Comparing the fatty acid composition of organic and conventional milk. J. Dairy Sci. 89:1938-1950.

Fillian, L., and S. Arazi. 2002. Does organic food taste better? A claim substantiation approach. Nutr. Food Sci. 32:153-157.

Griinari, J. M., and D. E. Bauman. 1999. Biosynthesis of conjugated linoleic acid and its incorporation into meat and milk in ruminants. Pages 180-200 in Advances in Conjugated Linoleic Acid Research. M. P. Yurawecz, M. M. Mossoba, J. K. G. Kramer, M. W. Pariza, and G. Nelson, ed. Am. Oil Chem. Soc., Champaign, IL.

Haffner, T., A. Nordsieck, and R. Tressl. 1996. Biosynthesis of $\delta$ jasmin lactone ( = (Z)-dec-7-eno-5-lactone) and (Z,Z)-dodeca-6,9dieno-4-lactone in the yeast Sporobolomyces odorus. Helv. Chim. Acta 79:2088-2099.

Hu, F. B., M. J. Stampfer, J. E. Manson, A. Ascherio, G. A. Colditz, F. E. Speizer, C. H. Hennekens, and W. H. Willet. 1999. Dietary saturated fatty acids and their food sources in relation to the risk of coronary heart disease in women. J. Am. Clin. Nutr. 70:1001-1008.

Hu, F. B., and W. H. Willett. 2002. Optimal diets for the prevention of coronary heart disease. J. Am. Med. Assoc. 288:2569-2578.

Hulshof, P. J. M., T. van Roekel-Jansen, P. van de Bovenkamp, and C. E. West. 2006. Variation in retinol and carotenoid content of milk and milk products in the Netherlands. J. Food Comp. Anal. 19:67-75.

Ip, C., S. F. Chin, J. A. Scimeca, and M. W. Pariza. 1991. Mammary cancer prevention by conjugated dienoic derivative of linoleic acid. Cancer Res. 51:6118-6124.

Jahreis, G., J. Fritsche, and H. Steinhart. 1997. Conjugated linoleic acid in milk fat: High variation depending on production system. Nutr. Res. 17:1479-1484.

Kelly, M. L., E. S. Kolver, D. E. Bauman, M. E. van Amburgh, and L. D. Muller. 1998. Effect of intake of pasture on concentrations of conjugated linoleic acid in milk of lactating cows. J. Dairy Sci. $81: 1630-1636$

Khanal, R. C., T. R. Dhiman, A. L. Ure, C. P. Brennand, R. L. Boman, and D. J. McMahon. 2005. Consumer acceptability of conjugated linoleic acid-enriched milk and Cheddar cheese from cows grazing on pasture. J. Dairy Sci. 88:1837-1847.

Kosikowski, F. V., and V. V. Mistry. 1997. Cheese and Fermented Milk Foods. 3rd ed. Vol. 1: Origins and Principles. Kosikowski LLC, Westport, CT.

Laird, D. T., S. A. Gambrel-Lenarz, F. M. Scher, T. E. Graham, and R. Reddy. 2004. Microbiological count methods. Pages 249-268 in Standard Methods for the Examination of Dairy Products. 17th ed. H. M. Wehr and J. F. Frank, ed. Am. Publ. Health Assoc., Washington, DC.

Lawless, F., C. Stanton, P. L'Escop, R. Devery, P. Dillon, and J. J. Murphy. 1999. Influence of breed on bovine milk cis-9, trans-11conjugated linoleic acid content. Livest. Prod. Sci. 62:43-49.

Meilgaard, M. C., G. V. Civille, and B. T. Carr. 1999. Sensory Evaluation Techniques. 3rd ed. CRC Press, Boca Raton, FL.

Mertens, D. R. 1973. Application of theoretical mathematical models to cell wall digestion and forage intake in ruminants. PhD Dissertation. Cornell Univ., Ithaca, NY.

Organic Trade Association. 2006. 2006 Manufacturer Survey. Available: http://www.ota.com Accessed Jan. 7, 2007.

Panfili, G., P. Manzi, and L. Pizzoferrato. 1994. High-performance liquid chromatographic method for the simultaneous determination of tocopherols, carotenes, and retinol and its geometric isomers in Italian cheeses. Analyst 119:1161-1165.

Schroeder, G. F., J. J. Couderc, F. Bargo, and D. H. Rearte. 2005. Milk production and fatty acid profile of milk fat by dairy cows fed a winter oats (Avena sativa L.) pasture only or total mixed ration. N. Z. J. Agric. Res. 48:187-195.

Shipe, W. F., R. A. Ledford, R. D. Peterson, R. A. Scanlan, H. F. Geerken, R. W. Dougherty, and M. E. Morgan. 1962. Physiological mechanisms involved in transmitting flavors and odors to milk. II. Transmission of some flavor components of silage. J. Dairy Sci. 45:477-480.

Toso, B., G. Procida, and B. Stefanon. 2002. Determination of volatile compounds in cows' milk using headspace GC-MS. J. Dairy Res. 69:569-577.

Urbach, G. 1990. Effect of feed flavor in dairy foods. J. Dairy Sci. 73:3639-3650

USDA, Agric. Marketing Service. 2006. Code of Federal Regulations, Title 7, Chapter I, Part 205, National Organic Program, Washington, DC.

US Government Accountability Office. 2004. Dairy history: Information on milk prices, factors affecting prices, and dairy policy options. GAO-05-50, December 2004. US Govt. Accountability Off., Washington, DC.

Whetstine, M. E., K. R. Cadwallader, and M. A. Drake. 2005. Characterization of aroma compounds responsible for the rosy/floral flavor in Cheddar cheese. J. Agric. Food Chem. 53:3126-3132.

White, S. L., G. A. Benson, S. P. Washburn, and J. T. Green. 2002. Milk production and economic measures in confinement or pasture systems using seasonally calved Holstein and Jersey cows. J. Dairy Sci. 85:95-104.

White, S. L., J. A. Bertrand, M. R. Wade, S. P. Washburn, J. T. Green, and T. C. Jenkins. 2001. Comparison of fatty acid content of milk from Jersey and Holstein cows consuming pasture or a total mixed ration. J. Dairy Sci. 84:2295-2301.

Yiridoe, E. K., S. Bonti-Ankomah, and R. C. Martin. 2005. Comparison of consumer perceptions and preference toward organic versus conventionally-produced foods: A review and update of the literature. Renew. Agric. Food Sys. 20:193-205. 